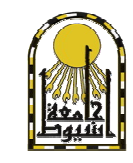

AUCES

\title{
TREATMENT OF THE MANGANESE ORE FROM BOSHOYA LOCATITY OF HALAEB AT THE EASTERN DESERT OF EGYPT
}

A. A. Zahran, S. I. Youssef and A. S. Khalil

Tabbin Institute for Metallurgical Studies (TIMS), POB 109, Helwan, Cairo, Egypt

ABSTRACT:

Treatment of the Boshoya locality manganese was conducted by reduction roasting followed by magnetic separation. For this propose, representative sample was crushed, mixed with varying amounts of minus one millimeter coal, and roasted under varying temperatures and duration periods. Mixing with $10 \%$ minus one $\mathrm{mm}$ coal, roasting at temperature of $800^{\circ}$ for 45 min duration were found to be optimum. Twelve magnetic separation tests were conducted on the roasted manganese ore. High $\mathrm{MnO2} \%$ grade of $63.2 \%$ and recovery of $\mathbf{4 0 . 6} \%$ from a feed grade of $38 \%$ MnO2 was obtained in the non-magnetic portion for a size of $-2+1 \mathrm{~mm}$ using optimum roasting parameters, drum speed of 60 R.P.M and coil current of 2 amperes (The maximum $=3$ amp).

High $\mathrm{MnO2} \%$ recovery of $96.7 \%$ at $\mathrm{MnO2} \%$ grade of $48.8 \%$ was obtained in the magnetic portion for a size of $\mathbf{- 1} \mathbf{~ m m}$ using optimum roasting parameters, drum speed of 60 R.P.M and coil current of 3 amperes. Several valuable conclusions were drawn and a recommendation was forwarded for future work.

\section{INTRODUCTION:}

Manganese is used in Steel Making as deoxidant and desulfurizing agent. Also, it is used for producing Ferromanganese alloy. Also Manganese dioxide is used for producing dry batteries [1].
The top producing countries for manganese ore (for 2007) are, South Africa (2.3 Mt), Australia (2.2 Mt) China (1.6 Mt). The production of the mentioned three countries reached $53 \%$ of the 
total international production (11.6 Mt) for the year 2007 [1].

The Egyptian production of manganese ore for the year 2007 reached 130,000 tons from which 83,400 tons were exported at a price ranging from 364.77 to 670.33 Egyptian pound per ton [2].

Several manganese deposits are recorded in Sinai and Eastern Desert. Um Bogama manganese deposits are located $20 \mathrm{~km}$ east of Suez gulf. The mentioned deposits occur within the diolomitic limestone belonging to the Middle Carboniferous age. The minerals of Um Bogama deposits are pyrolusite and Psilomelane. The reserves reach a value of 3 million tons with a grade ranging from 22 to $27 \%$. Sharm El Shikh manganese deposits are located south of Sinai. They occur within conglomerates belonging to the Cretaceous age. The reserves are about 30000 tons with Mn\% grade of $25 \%$ [1].
The manganese deposits in Eastern desert are located in Elba, Eish El Melah, Sakya. The reserves are being estimated, while the Mn grade is about $45 \%$. Other manganese deposits are recorded in Halaeb.

The geology of Halaeb was investigated in various works $[2,3]$. Attia was the first to report about Halaeb deposits [2]. Another work by El Shazly et al. [3] reported on the presence of pyrolusite, magnetite and cryptomelane. Ramadan et al (1999) reported that 24 manganese veins were found at both ends of $290^{\circ}-310$ NW-ES fault zone. At Shalateen-Halaeb district these veins were formed most probably due to the hydrothermal activity following the basaltic activity associated with the Red sea rifting. 


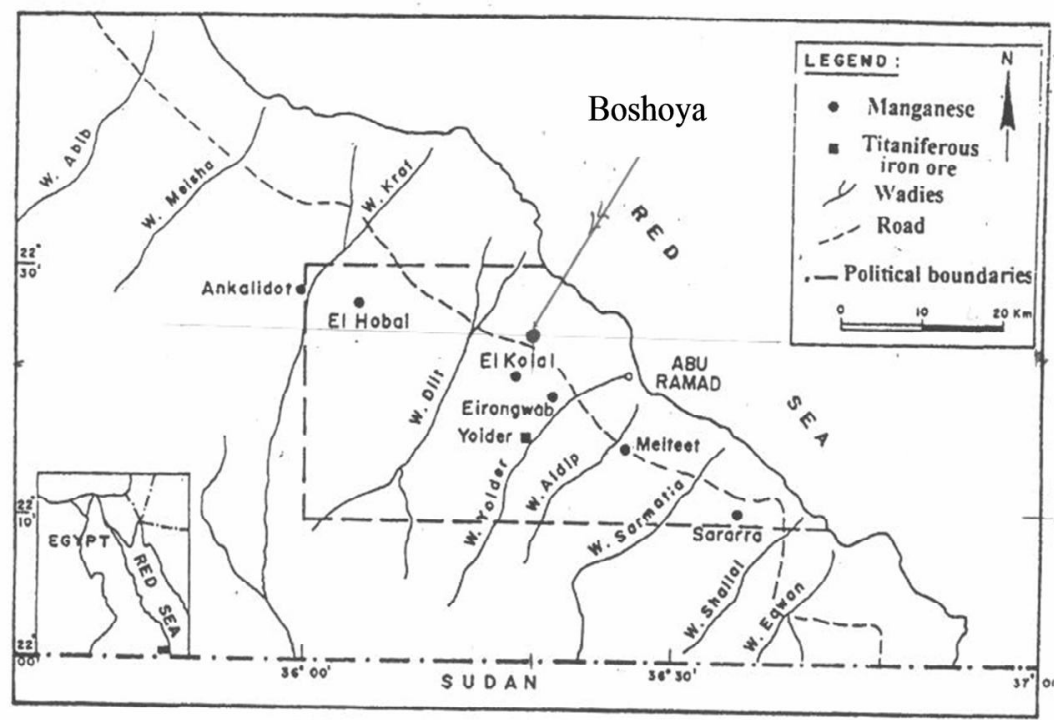

Fig (1) Map of the studied area, the Halaeb manganese deposits are found in Kolal, Eironnwab and Wadi Bashoya localities as shown.

This paper is concerned with upgrading the manganese ore located at Bashoya locality. This locality occur between latitude $22^{\circ} 21^{\prime} 30^{\prime \prime}-222300 \mathrm{~N}$ and longitude $36^{\circ} 18^{\prime}$ $00^{\prime \prime}, 3^{\circ} 1^{\prime} \mathbf{0 0}^{\prime \prime} \mathrm{E}$. It is considered the best new occurrence that has a total area of $10 \mathrm{~km}$. The Miocene to post Miocene sediments are encountered as low hills, that traversed by manganese veins and lenses.

Pervious efforts, on the same ore, used magnetic separation and shaking table (1). The results of magnetic separation gave Mn\% grade of $16.72 \%$ at $\mathrm{Mn} \%$ recovery of $90 \%$ in non magnetic portion from Mn\% starting analysis of $17.74 \%$ and $M n \%$ grade of $34.52 \%$ at a recovery of $8.73 \% \mathrm{Mn}$ in the magnetic portion. Shaking table tests were tried but Mn\% grade in the coarse and fine fractions were not satisfactory.
The present paper aims to upgrade the Haleab manganese ore using reduction roasting followed by magnetic separation. 


\section{(1) Theoretical Foundation:}

Reduction roasting had some commercial applicants in Europe [8]

The Minnesota School of Mines determined the following conditions for upgrading low grade hematite;

1. The temperature should exceed $400^{\circ} \mathrm{C}$ and small increase in temperature affects considerable increase in efficiency.

2. Efficiency increases with the increase in duration times.

3. Efficiency increases with the decrease in the size of particles.

Magnetic separation is based on the competition between magnetic force (Fm) and other forces such as centrifugal force $(\mathrm{Fr})$

$\mathbf{F m}=1 / 2$ vo $\mathrm{k} v \nabla \mathbf{H} 2$

vo $=$ permeability of free space $=4 \pi x$

10-7 Hm-1

$K=$ volume susceptibility

$v=$ volume of particle

$H=$ magnetic field strength Am-1

$\nabla=$ operator

Svoboda (1987) discussed the selection of magnetic separation technique. If the size of particles to be treated is greater than 75 um dry or wet can be considered. If the size is less than $\mathbf{7 5}$ um the wet separation is appropriate.

\section{(2) Experimental:}

\section{1- Equipment:}

The following equipment were used for the tests Laboratory Jaw crusher (Denvor type), screen set, Johnson splitter, muffle furnace, thermocouple, and laboratory magnetic separator (Carpco type).

\section{2- Material:}

Fifty kilograms were obtained from the Bashoya manganese deposit. The ore was crushed, subjected to coning and quartering. A quarter was selected. A representative sample was drawn for rock characterization and crushed to $-2+1 \mathrm{~mm}$, and $-1 \mathrm{~mm}$. In addition, coal was crushed to $-1 \mathbf{~ m m}$ and mixed with the manganese ore for roasting purpose.

3- Ore characterization:

A representative sample drawn from the crushed ore was sent to the laboratories of the Egyptian Mineral Resources Authority for analysis by $\mathrm{X}$ ray fluorescence. See table (1). In addition we analyzed the sample using 
scanning electron microscopy (FEI Inspect S-50 supplied with Bruker Quantax EDS Detector) in TIMS. Fig. (2) Shows a typical crushed sample and Fig (3) shows the $X$ - ray Energy Dispersive Spectroscopy (EDS) analysis of a typical mineral particle depicted in Fig. (4) and table (2) indicates the elemental composition of the mineral.

\section{4- Roasting \& Magnetic parame-} ters:

Four sets including twelve tests were designed to investigate the roasting and magnetic parameters. Two sets were conducted to investigate the roasting parameters, while the other two sets were conducted, to investigate the effect of the magnetic parameters such as drum speed and magnetic field strength.

\section{5- Testing procedures:}

The first set, comprising test number 1,2 and 3 , with a fraction size $-2+1$ mm was mixed with $7 \%$ coal ground to minus $1 \mathrm{~mm}$. The roasting parameters were adjusted at $600^{\circ} \mathrm{C}, 800^{\circ} \mathrm{C}$ for duration of 30 and 45 minutes. An average drum speed of 60 R.P.M and over average magnetic field strength attain- ing $66 \%$ of the maximum fields were chosen. The details can be found in table (3).

The second set, comprising test number 4,5 and 6 , had the same fraction size, roasting and magnetic parameters as those given earlier for the first set. Only the amount of mixed coal was varied to $10 \%$ instead of $7 \%$ for the first set. The details a can be found in table (4).

The third set, comprising test 7,8 and 9 , with a fraction size of $-1 \mathbf{m m}$ was mixed with $10 \%$ coal ground to minus $1 \mathrm{~mm}$. The roasting temperature was kept at $800^{\circ} \mathrm{C}$ while the duration was 45 minutes. The drum speed was kept at 60 R.P.M while the magnetic field strength was increased to maximum value ( 3 amperes) during the first two tests $7 \& 8$. But the third test was conducted on an over average magnetic field. The details of this set were listed in table (5).

The fourth set, comprising test 10, 11 and 12 was conducted under the same size fraction, roasting parameters, coal mix and magnetic field strength used for the third set. The drum speed was changed to 60, 80 and 100 R.P.M. 
The details are listed in table (6).

\begin{tabular}{|c|c|}
\hline Oxides & $\%$ \\
\hline $\mathrm{SiO}_{2}$ & 4.95 \\
$\mathrm{TiO}_{2}$ & 0.07 \\
$\mathrm{Al}_{2} \mathrm{O}_{3}$ & 0.41 \\
$\mathrm{Fe}_{2} \mathrm{O}_{3}$ & 6.98 \\
$\mathrm{MnO}_{\mathrm{K}_{2} \mathrm{O}}$ & 34.76 \\
$\mathrm{Na}_{2} \mathrm{O}$ & 0.52 \\
$\mathrm{MgO}^{\mathrm{CaO}}$ & 0.54 \\
$\mathrm{P}_{2} \mathrm{O}_{5}$ & 0.94 \\
$\mathrm{Cl}$ & 21.86 \\
$\mathrm{SO}_{3}$ & 0.06 \\
$\mathrm{L.O.I}$ & 3.72 \\
\end{tabular}

Table (1). X ray fluorescence results for Boshoya locality

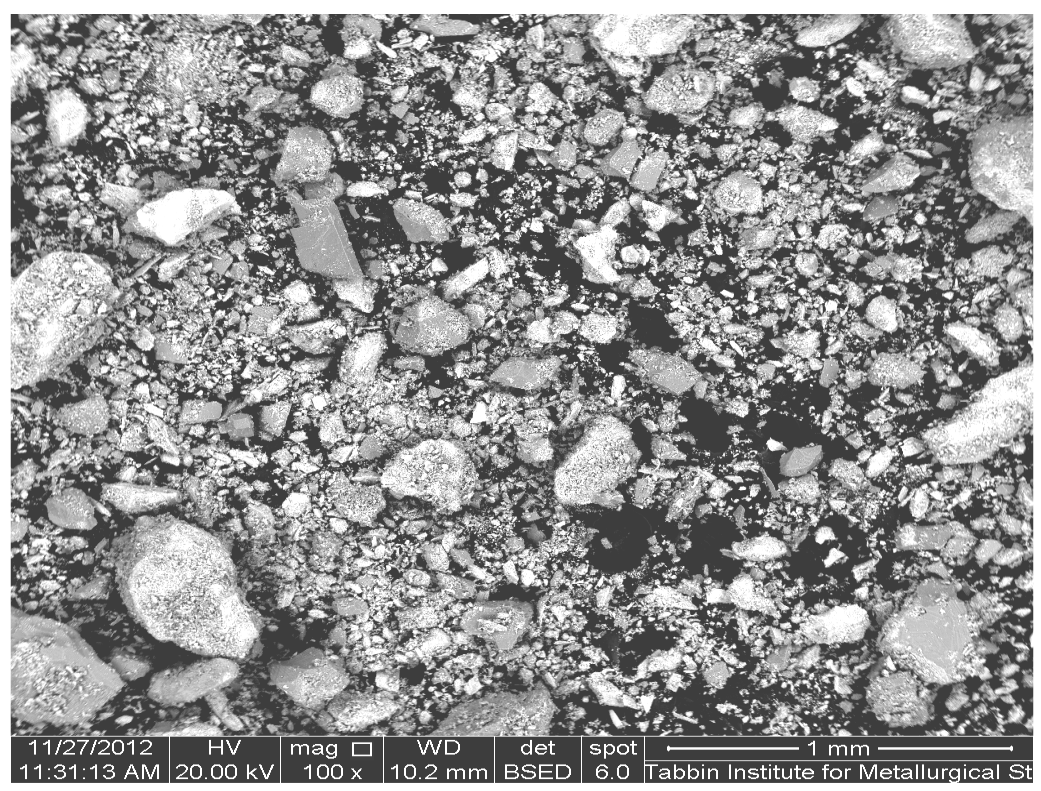

Fig. (2): A Back scattered scanning electron microscope (SEM) micrograph of a crushed sample 


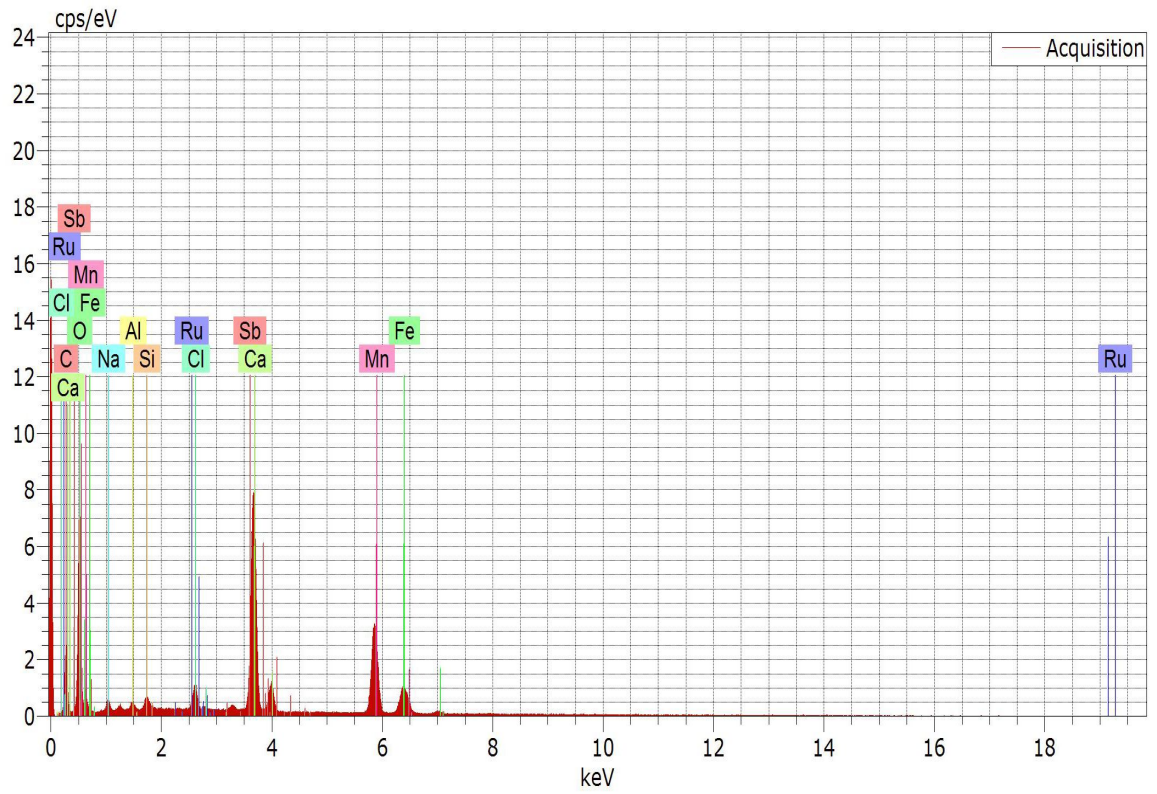

Fig. (3) The EDS analysis showing the elemental composition of a typical mineral particle which is shown in Fig. (4).

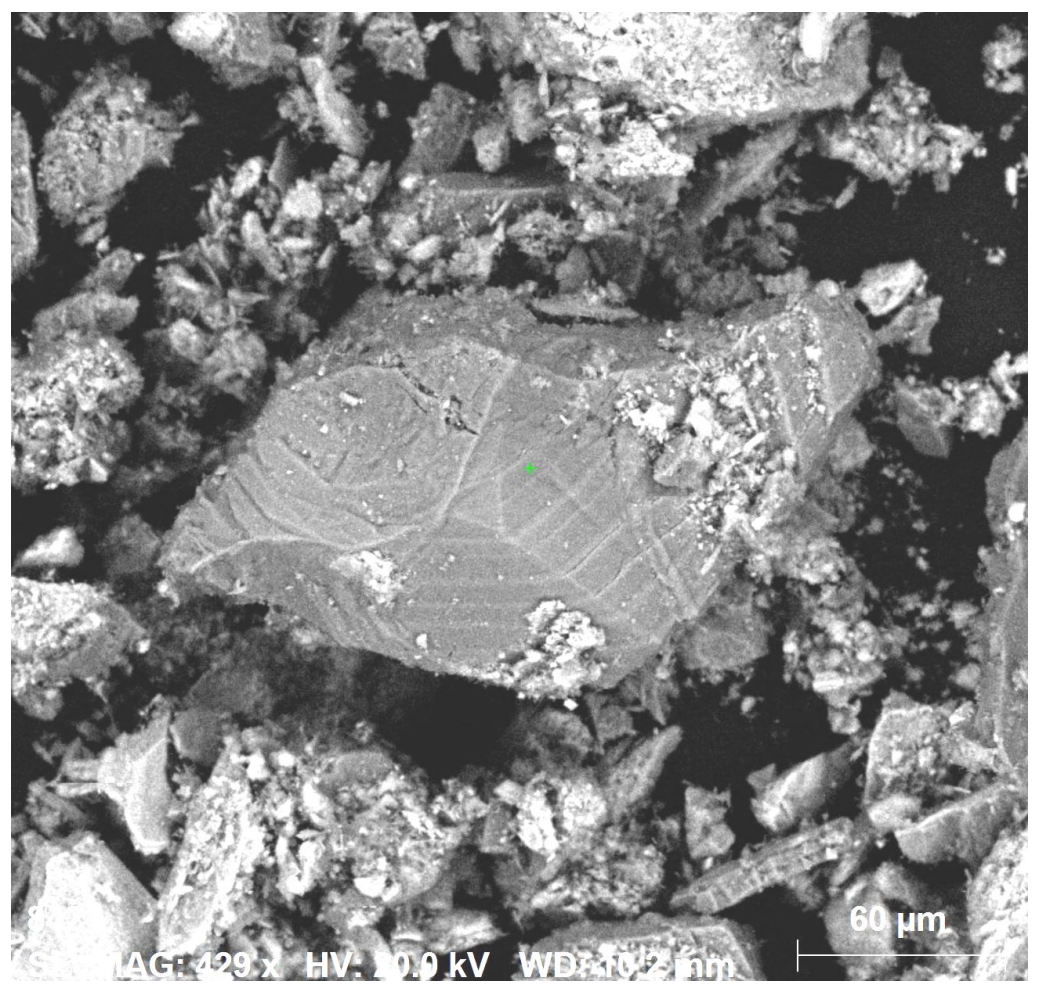

Fig. (4) SEM micrograph of a particle of a crushed sample 


\begin{tabular}{|c|c|}
\hline O & $37.17 \%$ \\
\hline K & $16.8 \%$ \\
\hline Mn & $14.39 \%$ \\
\hline Sb & $9.10 \%$ \\
\hline Fe & $4.92 \%$ \\
\hline $\mathrm{Na}$ & $1.58 \%$ \\
\hline Cl & $1.22 \%$ \\
\hline Si & $0.67 \%$ \\
\hline Al & $0.52 \%$ \\
\hline
\end{tabular}

Table (2) The elemental composition (wt \%) of the particle

\begin{tabular}{|c|c|c|c|c|c|c|c|c|c|c|c|}
\hline \multirow{2}{*}{$\begin{array}{c}\text { Num } \\
\text { ber of } \\
\text { Test }\end{array}$} & \multirow{2}{*}{$\begin{array}{c}\text { Coal } \\
\text { Wt.\% }\end{array}$} & $\begin{array}{c}\text { Dura- } \\
\text { tion } \\
\text { min }\end{array}$ & \multirow{2}{*}{$\begin{array}{c}\text { Temp. } \\
{ }^{\circ} \mathbf{C}\end{array}$} & \multicolumn{2}{|c|}{ Mag. Par. } & \multicolumn{2}{c|}{ Feed } & \multicolumn{2}{c|}{ Mag. Port } & \multicolumn{2}{c|}{ Non. Mag. Port } \\
\cline { 5 - 11 } & & & R.P.M. & Amp & Wt.gm & $\begin{array}{c}\text { MnO } \\
\mathbf{2 \%}\end{array}$ & Wt.\% & $\begin{array}{c}\text { MnO2 } \\
\%\end{array}$ & Wt.\% & $\begin{array}{c}\text { MnO2 } \\
\%\end{array}$ \\
\hline 1 & & 30 & 600 & 60 & 2 & 100 & 31.9 & 37 & 34.7 & 61 & 31.2 \\
2 & $7 \%$ & 25 & 600 & 60 & 2 & 200 & 36.8 & 83 & 37.3 & 117 & 36.5 \\
3 & & 45 & 800 & 60 & 2 & 135 & 42.9 & 75 & 29.7 & 60 & 59.5 \\
\hline
\end{tabular}

Mag. Par.=Magnetic parameter

Mag. Port= Magnetic portion

Non. Mag. Port= Non Magnetic portion

Table (3) Magnetic roasting parameters and results of set 1 size fraction $(-2+1 \mathrm{~mm})$

\begin{tabular}{|c|c|c|c|c|c|c|c|c|c|c|c|}
\hline \multirow{2}{*}{$\begin{array}{c}\text { Num- } \\
\text { ber of } \\
\text { Test }\end{array}$} & \multirow{2}{*}{$\begin{array}{c}\text { Coal } \\
\text { Wt. } \\
\%\end{array}$} & $\begin{array}{c}\text { Dura- } \\
\text { tion } \\
\text { min }\end{array}$ & \multirow{2}{*}{$\begin{array}{c}\text { Temp. } \\
{ }^{\circ} \mathrm{C}\end{array}$} & \multicolumn{2}{|c|}{ Mag. Par. } & \multicolumn{2}{|c|}{ Feed } & \multicolumn{2}{|c|}{ Mag. Port } & \multicolumn{2}{c|}{ Non. Mag. Port } \\
\cline { 5 - 13 } & & & & R.P.M. & Amp & Wt.gm & $\begin{array}{c}\text { MnO2 } \\
\%\end{array}$ & Wt.\% & $\begin{array}{c}\text { MnO2 } \\
\%\end{array}$ & Wt.\% & $\begin{array}{c}\text { MnO2 } \\
\%\end{array}$ \\
\hline 4 & & 45 & 600 & 60 & 2 & 166 & 39 & 101 & 36.9 & 60 & 45.7 \\
5 & $10 \%$ & 45 & 800 & 60 & 2 & 82 & 38 & 62 & 29.8 & 20 & 63.2 \\
6 & & 45 & 800 & 60 & 2 & 165 & 47.8 & 85 & 36.6 & 80 & 59.9 \\
\hline
\end{tabular}

Table (4) Magnetic roasting parameters and results of set 2 size fraction $(-2+1 \mathrm{~mm})$

\begin{tabular}{|c|c|c|c|c|c|c|c|c|c|c|c|}
\hline $\begin{array}{c}\text { Number } \\
\text { of } \\
\text { Test }\end{array}$ & $\begin{array}{c}\text { Coal } \\
\text { Wt. } \%\end{array}$ & $\begin{array}{c}\text { Dura- } \\
\text { tion } \\
\text { min }\end{array}$ & $\begin{array}{c}\text { Temp. } \\
{ }^{\circ} \mathrm{C}\end{array}$ & \multicolumn{2}{|c|}{ Mag. Par. } & \multicolumn{2}{|c|}{ Feed } & \multicolumn{2}{|c|}{ Mag. Port } & \multicolumn{2}{|c|}{ Non. Mag. Port } \\
\hline $\begin{array}{l}7 \\
8 \\
9\end{array}$ & $10 \%$ & 45 & 800 & $\begin{array}{l}60 \\
60 \\
60\end{array}$ & $\begin{array}{l}3 \\
3 \\
2\end{array}$ & $\begin{array}{l}195 \\
194 \\
200\end{array}$ & $\begin{array}{l}47.1 \\
47.8 \\
41.5\end{array}$ & $\begin{array}{l}180 \\
184 \\
140\end{array}$ & $\begin{array}{l}48.1 \\
48.8 \\
42.0\end{array}$ & $\begin{array}{l}15 \\
10 \\
55\end{array}$ & $\begin{array}{l}34.8 \\
30.5 \\
44.1\end{array}$ \\
\hline
\end{tabular}

Table (5) Magnetic roasting parameters and results of set 3 size fraction (-1 mm) 
Ass. Univ. Bull. Environ. Res. Vol. 16 No. 2 October 2013

\begin{tabular}{|c|c|c|c|c|c|c|c|c|c|c|c|}
\hline \multirow{2}{*}{$\begin{array}{c}\text { Num- } \\
\text { ber of } \\
\text { Test }\end{array}$} & \multirow{2}{*}{$\begin{array}{c}\text { Coal } \\
\text { Wt. } \\
\%\end{array}$} & \multirow{2}{*}{$\begin{array}{l}\text { Dura- } \\
\text { tion } \\
\text { min }\end{array}$} & \multirow{2}{*}{$\begin{array}{c}\text { Temp. } \\
{ }^{\circ} \mathrm{C}\end{array}$} & \multicolumn{2}{|c|}{ Mag. Par. } & \multicolumn{2}{|c|}{ Feed } & \multicolumn{2}{|c|}{ Mag. Port } & \multicolumn{2}{|c|}{ Non. Mag. Port } \\
\hline & & & & R.P.M. & Amp & Wt.gm & $\begin{array}{c}\mathrm{MnO2} \\
\%\end{array}$ & Wt.\% & $\begin{array}{c}\text { MnO2 } \\
\%\end{array}$ & Wt.\% & $\begin{array}{c}\mathrm{MnO2} \\
\%\end{array}$ \\
\hline $\begin{array}{l}10 \\
11 \\
12\end{array}$ & $10 \%$ & 45 & 800 & $\begin{array}{c}80 \\
100 \\
60\end{array}$ & $\begin{array}{l}3 \\
3 \\
3\end{array}$ & $\begin{array}{l}180 \\
180 \\
180\end{array}$ & $\begin{array}{l}46.6 \\
42.9 \\
42.4\end{array}$ & $\begin{array}{l}150 \\
169 \\
162\end{array}$ & $\begin{array}{l}48.7 \\
44.1 \\
44.7\end{array}$ & $\begin{array}{c}26 \\
8 \\
14\end{array}$ & $\begin{array}{l}41.4 \\
32.6 \\
28.5\end{array}$ \\
\hline
\end{tabular}

Table (6) Magnetic roasting parameters and results of size fraction (-1 mm)

\begin{tabular}{|c|c|c|c|c|c|c|c|c|c|c|c|}
\hline \multirow[b]{2}{*}{$\begin{array}{c}\text { Test } \\
\text { Number }\end{array}$} & \multirow{2}{*}{$\begin{array}{c}\text { Feed } \\
\text { Start } \\
\text { Analysis } \\
\text { MnO2\% }\end{array}$} & \multicolumn{2}{|c|}{ Mag. Portion } & \multicolumn{2}{|c|}{ Non. Mag. Port } & \multirow[b]{2}{*}{$\begin{array}{c}\text { Test } \\
\text { Number }\end{array}$} & \multirow{2}{*}{$\begin{array}{c}\text { Feed } \\
\text { Start } \\
\text { Analysis } \\
\text { MnO2\% }\end{array}$} & \multicolumn{2}{|c|}{ Mag. Port } & \multicolumn{2}{|c|}{ Non. Mag. Port } \\
\hline & & MnO2\% & R\% & $\begin{array}{c}\mathrm{MnO2} \\
\%\end{array}$ & $\mathbf{R} \%$ & & & $\begin{array}{c}\mathrm{MnO2} \\
\%\end{array}$ & $\mathbf{R} \%$ & $\begin{array}{c}\mathrm{MnO2} \\
\%\end{array}$ & $\mathbf{R} \%$ \\
\hline 1 & 31.9 & 34.7 & 40.3 & 31.2 & 59.7 & 7 & 47.1 & 48.1 & 94.3 & 34.8 & 5.6 \\
\hline 2 & 36.8 & 37.3 & 42.0 & 36.5 & 58.0 & 8 & 47.8 & 48.8 & 96.7 & 30.5 & 3.3 \\
\hline 3 & 42.9 & 29.7 & 38.4 & 59.5 & 61.6 & 9 & 41.5 & 42.0 & 70.8 & 44.1 & 29.2 \\
\hline 4 & 39.0 & 36.9 & 57.6 & 45.7 & 42.3 & 10 & 46.6 & 48.7 & 87.2 & 41.4 & 12.8 \\
\hline 5 & 38.0 & 29.8 & 59.4 & 63.2 & 40.6 & 11 & 42.9 & 44.1 & 96.6 & 32.6 & 3.4 \\
\hline 6 & 47.8 & 36.6 & 39.4 & 59.9 & 60.6 & 12 & 42.4 & 44.7 & 94.8 & 28.5 & 5.2 \\
\hline
\end{tabular}

Table (7) grade and calculated recovery of the four sets 


\section{DISCUSSION:}

The results of test 3 indicated in table (7) gave a grade of $\mathbf{5 9 . 5 \%}$ $\mathrm{MnO2 \%}$ and a recovery of $61.6 \%$ $\mathrm{MnO2 \%}$ in the non magnetic portion. This may be attributed to the roasting temperature of $800^{\circ} \mathrm{C}$ and duration of 45 minutes which can be considered optimum roasting parameters.

The results of test 5 indicated in table (7) gave a grade of $63.23 \%$ $\mathrm{MnO2} \%$ at a recovery of $\mathbf{4 0 . 6 \%}$ in the non magnetic portion. This result may be attributed to the increased amount of coal \% $(10 \%)$. This coal percentage may be considered optimum to obtain higher Mn\% grade in the non magnetic portion.

The results of test 8 indicated in table (7) gave the highest recovery of $\mathrm{MnO2} \%(96.7 \%)$ in the magnetic portion. This result mat be attributed to the maximum field strength (3 amp) used and the size of minus 1 mm. The maximum field strength as well as the minus 1 size may be considered optimum to obtain maximum recovery in the magnetic portion.

The results of test 10 indicated in table (7) conducted at (80 R.P.M.) gave a $\mathrm{MnO2 \%}$ recovery of $87.2 \%$ which is smaller than the $\mathrm{MnO2 \%}$ recovery (94.8) obtained for test 8 conducted at 60 R.P.M. This result may be attributed to the effect of centrifugal force which value in the case of test number 10 exceeds the corresponding value for test 8 ; consequently, more Mn particles will be detached from the drum.

\section{Conclusions:}

1- The best roasting parameters are $800^{\circ} \mathrm{C}$ at duration of 45 minutes. These parameters can be considered the optimum roasting parameters. 
2- The highest $\mathrm{MnO2 \%}$ grade $(63.2 \%)$ can be obtained in the non magnetic portion for coal mix of $10 \%$ by weight of ore using optimum roasting parameters, average R.P.M (60) and over average magnetic field (2amp).

3- The highest $\mathrm{MnO2 \%}$ recovery of $(96.7 \%)$ can be obtained in magnetic portion using coal mix of $10 \%$ by weight of ore using optimum roasting paters,R.P.M of 60 and high strength magnetic field of 3 amp.

\section{Recommendation:}

Upgrading manganese ore of Halaeb deposits by reduced roasting followed by magnetic separation should be introduced in the Egyptian mining practice to add a considerable benefit for the Egyptian economy. 


\section{REFERENCES:}

Attia, M.I., 1956. Manganese Deposits of Egypt Geol. Congress, 20 th Mexico symposium sobre do manganese; Vol. 2, Affric, pp.143-171.

El Shazly, E. M., and Saleeb, G.S., 1959. Contribution To The Mineralogy of Egyptian Manganese Deposits, Econ. Geolo., V.54, pp.873-888.

Ramadan, T. M., Yehia, M. A., Hassan, M. M. and Durgham, L., A., 1999. Contribution to Geology, Structures and Geochemistry of the ironmanganes-barite veins, Shalateen-Halaeb District, Eastern Desert Egypt, AlAz, Bull, Sci. Vol.No. 1(June), pp. 329-343.

Abd-El Monem A,M., et. al ( 2007), G.A., Study of mining and treatment of Halaeb manga nese ore Project, Min., Dept., TIMS, 2007.

Svoboda, J., (1987), Magnetic methods for the Treatment of Minerals, New York.

Taggart, A.F., (1954), Hand Book of Mineral Dressing, John Wiley and Sons Inc., New York.

U. S. Geological Survey (2008). Mineral Commodity, January.

Wadi, H. H. Schulz, N.E., (1960); Magnetic roasting of iron ores in a traveling Greater Roaster, Min., Eng. P. 1-5.

Wills, B., A., (1993), Mineral Processing Technology. New York

مجلة المناجم والمحاجر - العدد الرابع والعشرين - مابـ

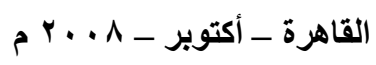




\section{معالجة خام الإنبمنهر \\ * ملدل عبد الحمهيد زهران}

"معها التبيين للاراسات المعدنية- التبين- حلوان"

تم معالجة خام المنجنيز بمنطقة (بوشويا) بواسطة التحميص الاختزالي ثم الفصل المغناطيسي ولإجراء

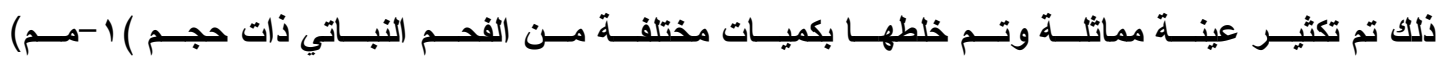
وتم التحميص تحت درجات حرارة وأزمنة مختلفة.

وتبين أن نسبة خلط الفحم النباتي التي تساوى • 1\% تعتبر مثالية وكذلك درجة حرارة . . 1 م وفترة ذماتيه هـ ؛ دقيقة تعتبر أيضاً مثالية.

تم إجر اء r I اختبار للفصل المغناطيسي على الخام المحمص. ثم التوصل إلى نسبة تحليل ثاني أكسيد المنجنيز

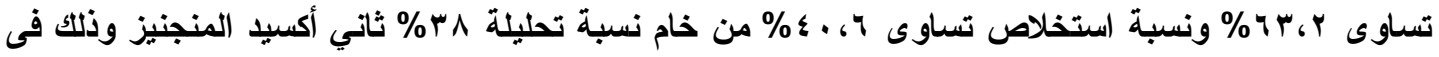

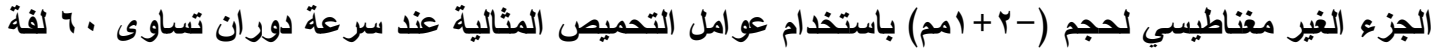

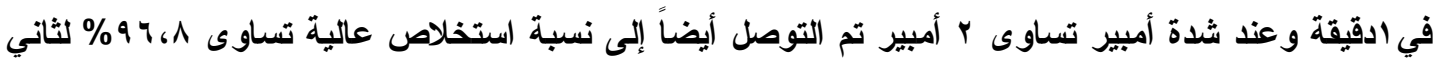

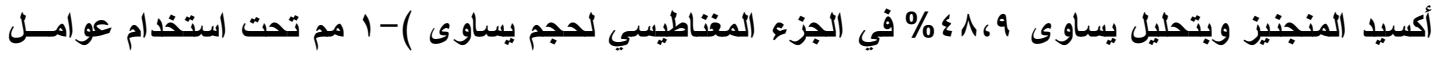

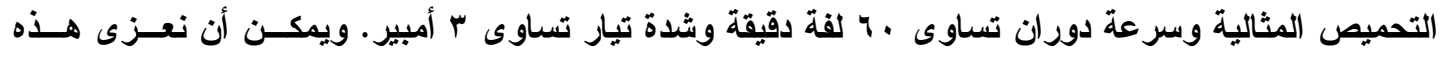
النتائج إلى درجة التحرير للحبيبات كنلك شدة المجال المغناطيسي. إن نسبة الاستخلاص العالية التي تم الحصول عليها في الثانية يمكن أن تعود إلى درجة التحرير العالية كذلك إلى شدة المجال المغناطيسي العالية. 